Kohl: a Journal for Body and Gender Research Vol. 3, No. 2 (Winter 2017)

\title{
A Queer Ritual
}

Bel South 


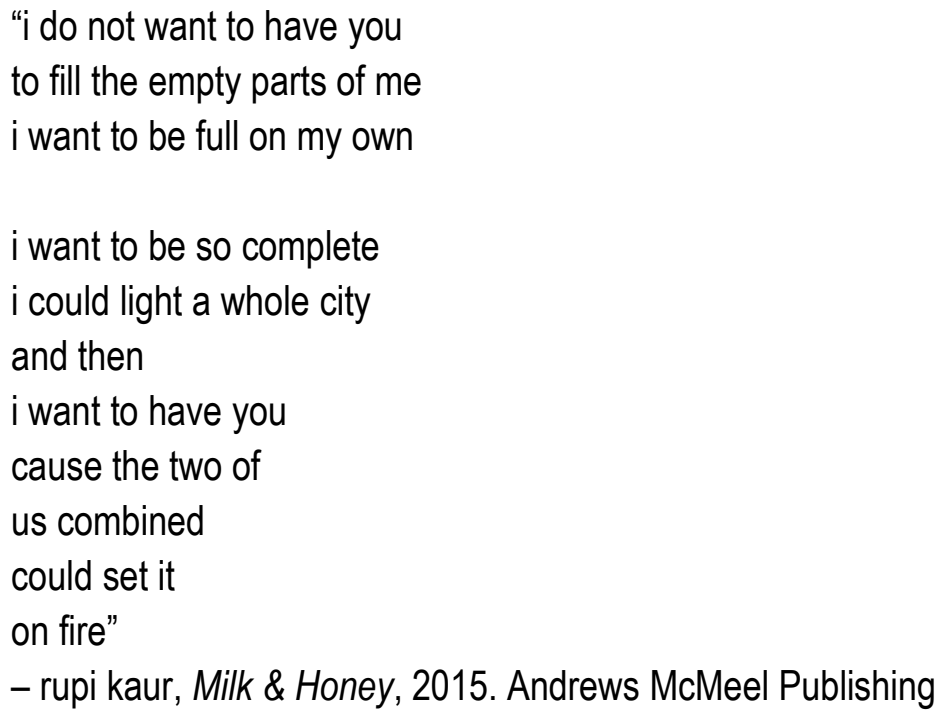

It was around August, springtime in the Southern hemisphere. We picked a fancy restaurant, one with too many courses and the prerequisite bottles of smooth South African red. We got dressed up in our grown-up clothes. And we held hands. As the crimson flowed, we ruminated over how the last year of our relationship had unfolded. You described it as "our fateful experiment" in queering love.

It felt good to reflect, and to be a little critical of this thing we now openly and honestly identified as love. I thought back on a history of lovers, a history of working to live up to some strange heteronormative expectation of what it means to be the perfect woman, the ideal girlfriend, the domestic lady, the sex goddess, all at the same time. But we decided that we wanted to build something different, something that reflected our politics in the world. From the way we talk to each other, to the way we touch each other, and all that lies in-between. Because that is what queering love could look like.

Our realisation, our light bulb moment in the warmth of one-ness over wine, was that our love journey aspired to confront these questions about queer love - to bring them to light, to grapple with them, to hold them gently. Over the last year, we had consciously, slowly begun to shed those layers of heteronormative history and to shatter those unseen shackles. One of the challenges of queering love is overcoming the assumptions that come with the term "relationship" in a hetero-patriarchal capitalist society. Assumptive definitions of monogamy and longevity, of possession and faithfulness, of loyalty and pride. We deliberately unpacked these words and gave them new definitions, in contrast and sometimes in contradiction to what they mean in the world.

You pulled out a draft dinner agenda, rolling over the possible topics, your queering love list included health, wealth, sex, family, future, and others. This list reminded me that for us everything is on the table, so we can support each other, so we can grow individually and together, so things do not remain unsaid and unheard and undreamed. We drifted onto our current decision to be monogamous. We discussed the nature of power, definitions of beauty and how they affect how the world reads us. We discussed how if you were drawn to another human, as is want to happen, we would have this discussion of powerprivilege-desire again and again and again to find our way to a new norm. Even if it's hard. Because that is what queering love feels like. 
As the evening extended into night, there was the expected side-eye from our table neighbours, same from the oh-so-polite waiter, those glances that reminded us that we are Other. The mood, the lighting, the loving-looks revealed our romantic rendezvous, an affair of flames, a queer date. But for that night, we felt safe and we were in love in the world, we could be witnessed - our love was visceral, everyone could see it, feel it, taste it, witness it. Would it be that every loving couple could be witnessed as we were that night.

Seated across the table from you, bypassing the cutlery and candles our fingers touch.

I quietly hum, through small sips,

"I love how you..."

lust my body.

Sometimes gently, sometimes roughly.

The sounds and sights of mutual pleasure.

"I love when you..."

share your activism.

Challenging my mind, my politics.

Boldly, kindly holding your ground.

"I love that you..."

love yourself.

(Most of the time).

You beam. Your whole-self absorbing my love of your love.

By the end we are wine high and love drunk.

That dinner was a microcosm of the year, that is what queering love tastes like. We shared with each other stories of triumph over The Man, reminding ourselves of the times we gave each other courage to stand our ground, celebrating our values and beliefs. In those moments we concretised our foundations, we fortified ourselves once again.

You were the one that told me that queer love has less to do with the sexual orientation or gender representation of whom we were fucking, and everything to do with a confrontation, a negotiation, and a naming of power between us - inside us - across the table expanse. Together we confronted our class differences, our gendered differences, our sexualized differences, even differences between what we choose to eat or drink or smoke. We named the power that laced our love. 
Kohl 3.2

shouted, violently

stormed against you.

That time I dismissed your life experience because it wasn't my privileged existence, or made decisions about our shared life absent of you.

Entrenching my power, negating yours.

No one should be the receptor of my rage, my anger, my frustration, my ignorance.

That evening we unpacked notions of violence. You taught me that my voice was a weapon, that my words could cut to the bone, that my tones could punch through any defense. And I knew I didn't want to be violent, towards anyone, let alone you. So I had to relearn conflict. I had to relearn how I wanted to love. Without this clarity and willingness to learn (or unlearn), queering love isn't possible because queer love is a communal project - it could never be a one person's job.

Finally, dinner was done. Licking the final morsels of chocolate dessert from your spoon, we paid the bill. And as we headed home, a queer home in the making, I thought to myself:

Blessed.

Let's slow dance to Sam Cooke

across the black and white tiles of our kitchen, and celebrate

this queer love

ritual. 